\title{
Diabetes and Host Resistance
}

\section{Effect of Alloxan Diabetes Upon the Phagocytic and Bactericidal Efficiency of Rat Leukocytes for Pneumococcus}

\author{
H. FRANCES BRISCOE AND FRED ALLISON, JR.
}

Division of Infectious Diseases, Departments of Medicine and Microbiology, University Medical Center, Jackson, Mississippi

Received for publication 2 July 1965

\section{Abstract}

Briscoe, H. Frances (University Medical Center, Jackson, Miss.), AND Fred Allison, JR. Diabetes and host resistance. I. Effect of alloxan diabetes upon the phagocytic and bactericidal efficiency of rat leukocytes for pneumococcus. J. Bacteriol. 90:1537-1541. 1965.-Chronic diabetes mellitus was induced in rats with alloxan monohydrate. Glycosuria persisted for the 6 weeks of study, but ketonuria was never encountered. The cellular composition of peritoneal exudate recovered from diabetic rats after starch aleuronat administration was the same as that obtained from normal rats. The quantity of exudate recovered from the diabetic rats was thought to be less than that obtained from normal rats subjected to the same irritant. Phagocytosis was found to be essentially the same for both diabetic and normal cells when suspended in normal saline. The killing efficiency of harvested peritoneal phagocytes suspended in saline from both diabetic and normal rats for type 1 pneumococcus was compared and no difference between the groups was found.

The following studies were performed to measure the influence of diabetes mellitus induced by alloxan upon the phagocytic and bactericidal capacity of peritoneal exudate leukocytes from the rat for encapsulated type I pneumococcus in vitro.

\section{Materials and Methods}

Animals. Male albino Sprague-Dawley rats weighing from 250 to $350 \mathrm{~g}$ were fed an antibioticfree diet and given water ad libitum. Each rat was weighed weekly.

Handling of exudate and bacterium. All animals were killed with chloroform, and the sterile 18-hr peritoneal inflammatory exudate produced by starch aleuronat was harvested aseptically by methods described previously (Allison and Adcock, 1964), with the exception that isotonic, pyrogenfree saline (Baxter Laboratories, Morton Grove, Ill.) containing $0.001 \%$ sodium heparin (Upjohn Co., Kalamazoo, Mich.) was used to suspend cells recovered from each rat. Washings from the peritoneum of five animals were pooled in conical tubes and centrifuged at $150 \times g$ at $4 \mathrm{C}$ for $5 \mathrm{~min}$. The pellet was then suspended in $5 \mathrm{ml}$ of heparinized saline for enumeration. After a final centrifugation, a dilution was made to give a concentration of $5 \times 10^{8}$ cells in a volume of $0.3 \mathrm{ml}$ (Allison and Adcock, 1964).

The same type I pneumococcus used in previous studies was handled in exactly the same way (Allison and Adcock, 1964). Mixtures of bacteria and leukocytes in a 2:1 ratio were placed on a suitable filter-paper surface for $30 \mathrm{~min}$ to permit phagocytosis. The bacterium-leukocyte mixture was then recovered by washing the filter-paper square with $1.0 \mathrm{ml}$ of heparinized saline to measure phagocytic activity and to assay bactericidal efficiency. The latter was accomplished by making slide cultures of the recovered mixtures. Slide cultures were also made of the original culture to assure adequate control of the system (Allison and Adcock, 1964). After slide cultures were incubated for $2 \mathrm{hr}$ at $37 \mathrm{C}$, each was stained with methylene blue and counts were made of single bacteria and of microcolonies that were found extracellularly and intracellularly, to tabulate the efficiency of killing.

Gross estimates of phagocytic viability were made with trypan blue supravital stains when the exudate was harvested and upon recovery from the filter-paper surface just prior to preparation of the slide cultures. No attempt was made to measure survival of leukocytes after their incubation in the agar cultures (Allison and Adcock, 1964). All specimens were coded for counting to minimize bias.

Statistical analysis of the data was performed by the method of Croxton (1953) for determining the significance of the difference between two samples.

Solutions and glassware. Solutions and reagents were prepared in pyrogen-free isotonic saline and were maintained aseptically. All glassware was siliconized and then washed free from chemicals 


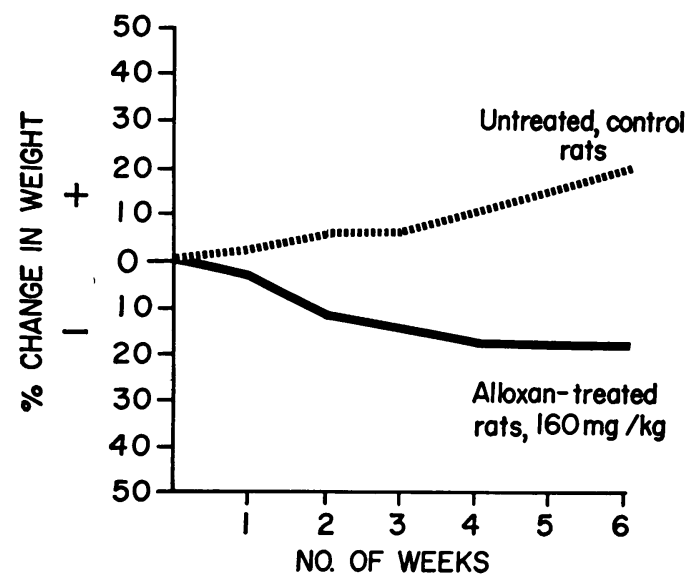

( $P=>0.001$ but $<0.005$ )

Frg. 1. Effect of alloxan diabetes upon the weight of rats during the 6 weeks prior to collection of exudate.

before heating for $2 \mathrm{hr}$ at $170 \mathrm{C}$ to render it free from bacterial pyrogen.

Induction of diabetes. A fresh $1.0 \%$ solution of alloxan monohydrate (Monarch Chemicals, Minneapolis, Minn.) was prepared for each experiment. Two injections, $160 \mathrm{mg} / \mathrm{kg}$ each (Sturtevant, 1956), were given intraperitoneally $48 \mathrm{hr}$ apart. At $48 \mathrm{hr}$ after the second dose, the urine of each rat was tested for sugar with Tes-Tape (Eli Lilly and Co., Indianapolis, Ind.). If no sugar was found in the urine, a third injection of alloxan was given 1 week after the first dose. Based on the work of others, it was expected that this method would induce chronic glycosuria in at least $60 \%$ of injected rats and that as many as $80 \%$ of these animals would survive for as long as the 6 weeks of experimentation (Sturtevant, 1956). With each group of 10 alloxan-treated rats, 6 untreated animals were fed similarly for control purposes.

\section{Results}

Effect of alloxan-induced diabetes upon rats. Of 154 animals given alloxan intraperitoneally, 58 remained diabetic for the 6 -week period of study and were thus suitable for experimental purposes. The diabetic rats were noted to be more susceptible to intermittent bacterial diseases, and 12 died of infection before the time of experimentation. However, the pathogenicity of the type I pneumococcus was not measured in the diabetic animals; 74 rats failed to remain diabetic, even though some of these animals were given a third injection of alloxan.

In Fig. 1 the influence of the diabetic state upon weight gain has been plotted against the gain in weight by a similar group of untreated animals. Although the diabetic rats exhibited
TABLE 1. Characteristics of exudate recovered $20 \mathrm{hr}$ after starch aleuronat administration intraperitoneally to untreated and alloxan-treated rats

\begin{tabular}{c|c|c|c|c|c|c}
\hline & \multicolumn{2}{|c|}{$\begin{array}{c}\text { No. of rats } \\
\text { used }\end{array}$} & \multicolumn{2}{|c|}{$\begin{array}{c}\text { No. of leukocytes } \\
\text { harvested }\left(\times 10^{8}\right. \\
\text { per ml) }\end{array}$} & \multicolumn{2}{|c}{$\begin{array}{c}\text { Per cent of poly- } \\
\text { morphonuclear } \\
\text { granulocytes }\end{array}$} \\
\cline { 2 - 5 } & Control & $\begin{array}{c}\text { Dia- } \\
\text { betic }\end{array}$ & Control & Diabetic & Control & Diabe tic \\
\hline 1 & 5 & 5 & 0.65 & 0.69 & 81 & 76.5 \\
2 & 5 & 9 & 0.92 & 1.41 & 66.5 & 74.5 \\
3 & 5 & 6 & 0.76 & 1.25 & 74.0 & 70.0 \\
4 & 5 & 7 & 1.05 & 1.20 & 74.5 & 69.2 \\
5 & 6 & 6 & 1.26 & 1.29 & 72.7 & 70.6 \\
\hline
\end{tabular}

glycosuria greater than $2 \%$, not a single animal developed ketonuria. It was also noted that the diabetic rats developed ruffled, uneven coats, appeared thinner, and consumed more water per day than the untreated group.

Influence of alloxan-induced diabetes upon the peritoneal exudate induced by alloxan. The number of leukocytes recovered per unit volume of exudate from the diabetic and control groups (Table 1) was the same, even though it was thought that a greater quantity of material was recovered from the control group. Unfortunately, the technique for harvesting did not permit the differences in volume to be quantitated accurately.

When the composition of the cellular exudates was compared by use of smears stained with methylene blue and Wright stain, no significant difference between the diabetic and control groups was found (Table 1). In general, at least $70 \%$ of the cells were polymorphonuclear neutrophilic granulocytes (PMNG); this figure is in keeping with previous findings (Allison and Adcock, 1964).

Effect of alloxan-induced diabetes upon phagocytosis. Ingestion of the encapsulated mousevirulent, type I pneumococcus was equally vigorous by PMNG from both groups of rats in each of five separate experiments (Table 2). Likewise, no statistical difference in the phagocytic index, i.e., numbers of bacteria within each PMNG, was noted (Table 2).

Effect of alloxan-induced diabetes upon bacterial killing by $P M N G$. The ability of peritoneal leukocytes, harvested from diabetic and untreated rats and suspended in isotonic saline, to kill engulfed type I pneumococcus was compared in slide cultures prepared from the phagocytosis mixtures recovered from the filter-paper surface. The viability of extracellular bacteria, as determined by microcolony formation, approached $\mathbf{9 5 \%}$ and was essentially equal in both groups of 
TABLE 2. Phagocytic and bactericidal efficiency of exudate leukocytes recovered $20 \mathrm{hr}$ after starch aleuronat administered intraperitoneally to untreated and alloxan-treated rats

\begin{tabular}{|c|c|c|c|c|c|c|c|c|}
\hline \multirow{3}{*}{ Expt no. } & \multicolumn{2}{|c|}{$\begin{array}{l}\text { Per cent surface } \\
\text { phagocytosis by } \\
\text { PMNG* }\end{array}$} & \multicolumn{2}{|c|}{ Phagocytic index $\dagger$} & \multicolumn{4}{|c|}{ Per cent bactericidal efficiency of PMNG* } \\
\hline & \multirow[b]{2}{*}{ Control } & \multirow[b]{2}{*}{ Diabetic } & \multirow[b]{2}{*}{ Control } & \multirow[b]{2}{*}{ Diabetic } & \multicolumn{2}{|c|}{ Control } & \multicolumn{2}{|c|}{ Diabetic } \\
\hline & & & & & $\begin{array}{c}\text { Viable } \\
\text { extracellular } \\
\text { bacteria }\end{array}$ & $\begin{array}{c}\text { PMNG showing } \\
\text { intracellular } \\
\text { killing }\end{array}$ & $\begin{array}{c}\text { Viable } \\
\text { extracellular } \\
\text { bacteria }\end{array}$ & $\begin{array}{l}\text { PMNG showing } \\
\text { intracellular } \\
\text { killing }\end{array}$ \\
\hline 1 & 30.9 & 29.2 & 4.0 & 2.3 & 97.5 & 97.0 & 96.0 & 96.5 \\
\hline 2 & 44.5 & 38.1 & 4.5 & 2.5 & 97.5 & 97.0 & 96.5 & 96.5 \\
\hline$\overline{3}$ & 45.0 & 46.4 & 4.0 & 3.0 & 91.5 & 95.5 & 93.0 & 95.0 \\
\hline 4 & 35.0 & 33.5 & 3.1 & 2.2 & 95.5 & 97.5 & 95.0 & 96.0 \\
\hline 5 & 32.6 & 31.5 & 4.2 & 2.5 & 92.5 & 98.5 & 94.5 & 96.0 \\
\hline Mean values & & & & & $94.9+2.5$ & $97.1+0.7$ & $95.0+1.2$ & $96.0+0.6$ \\
\hline
\end{tabular}

* The difference between the two groups of values was not statistically significant.

$\dagger$ Average number of bacteria identified within cytoplasm of each of 100 leukocytes. The difference between these values was not found to be significant statistically. The $P$ value was 0.15

experiments (Table 2). This indicated that cultural conditions were excellent and assured stable control of the experiments. It was, therefore, of critical importance to find that under these ideal circumstances microcolony formation within PMNG was essentially the same for both groups of experiments. Thus, no impairment in bactericidal efficiency could be found in leukocytes recovered from chronically diabetic rats.

\section{Discussion}

Despite a low yield of rats with protracted glycosuria after alloxan administration, a sufficient number survived for the 6 weeks of experimentation. Even though blood-sugar determinations were not performed to confirm hyperglycemia, persistent glycosuria left no doubt that the animals had uncontrolled diabetes mellitus. Failure to detect ketonuria at any time was somewhat surprising, but probably meant that the diabetes was mild and that the experiments were concluded before substantial ketone production developed.

Our finding that neither phagocytosis nor the intracellular killing of type I pneumococcus by PMNG recovered from the peritoneal exudate of alloxan-treated rats was impaired agreed with the results of Cruickshank and Payne (1949) and Marble, White, and Fernald (1938). Wertman and Henney (1962), on the other hand, suggested that the phagocytic efficiency of cells from diabetic animals was diminished. Bybee and Rogers (1964) reported that human leukocytes recovered from venous blood of hyperglycemic, but nonketotic, diabetics equaled the phagocytic function of white blood cells obtained from blood of nondiabetic donors. In studies currently under- way in our laboratories, Crosby (unpublished data) has noted essentially the same results with PMNG from nonketotic diabetic patients, but under different experimental conditions from those used by Bybee and Rogers (1964). A significant reduction in phagocytic efficiency was noted by Bybee and Rogers (1964) when leukocytes were studied from patients with ketoacidosis due to poorly controlled diabetes mellitus. Of even greater relevance are recent observations reported by Drachman (1965), who utilized leukocytes recovered from peritoneal exudate and from circulating blood after rats had been made chronically diabetic with alloxan. He found that phagocytosis by peritoneal leukocytes from normal and diabetic rats, suspended in autologous serum, was impaired only after the glucose content had been set at high levels. Leukocytes suspended in whole blood behaved differently in that they ingested type 25 pneumococcus with vigor even when glucose levels were elevated. These results seemed to indicate that phagocytic cells from exudate were altered and that they were more fragile than circulating leukocytes. As a consequence, the ability of exudate phagocytes to engulf bacteria was substantially reduced by the high levels of glucose in the suspending medium. Experimental evidence to suggest that exudate leukocytes actually are more fragile after having undergone diapedesis has been reported previously (Allison and Adcock, 1964). The experiments of this report were performed with the peritoneal exudate PMNG recovered from both diabetic and nondiabetic rats, and suspended in isotonic saline, with no added serum; the effect of different glucose concentrations was not measured. 
Even though there may yet be an element of uncertainty concerning the influence that the deranged carbohydrate metabolism of diabetes mellitus may exert upon the efficiency of phagocytic cells in the disposal of pathogenic bacteria, our results, as well as those reported by Bybee and Rogers (1964) and Drachman (1965), tend to support the idea that PMNG from diabetics is not altered by the disease per se. It is also worth keeping in mind that many bacterial infections encountered in diabetic patients not only become established before ketosis is detected but may also be decisive in provoking a breakdown in acid-base balance that eventually leads to uncompensated metabolic acidosis. For this reason, we must consider that factors other than the phagocyte, namely, the osmotic effects of hyperglycemia, may be important with reference to the more general problem of infection in diabetics.

In keeping with the preceding possibility, it is worth noting that the cellular elements found in the inflammatory exudate elicited by starch aleuronat were qualitatively similar for the diabetic and the control rats (Table 1). It was thought, however, that diabetic animals accumulated a smaller volume of exudate. Even though this difference was not quantitated precisely, it was considered that dehydration produced by uncontrolled glycosuria probably reduced the volume of exudate. The protracted negative nitrogen balance induced by chronic diabetes could have influenced the volume of exudate (Fig. 1), but we know of no data pertaining to this possibility. Dietary deprivation per se, as in acute starvation, has been found by Smith and Dubos (1956) to decrease resistance to bacterial infection, although the means for this effect has not been described. Chronic caloric restriction, on the other hand, failed to modify the response to infection (Smith and Dubos, 1956). Perhaps of greater relevance was the work of Miles, Miles, and Burke (1957), who found that the intraperitoneal administration of a hypertonic glucose solution substantially inhibited the edema and cellular exudation generated locally by subcutaneous challenge with certain pathogenic bacteria. The infection that developed after such a challenge was enhanced. Although Miles et al. (1957) failed to provide an explanation for their finding, the exacting temporal relationships of the experiment suggested to them that the hypertonic glucose caused dehydration and transient hypovolemia, which in turn impaired the peripheral circulation. This condition has since been referred to as dehydration shock (Miles et al., 1957).
Evidence of a different sort was reported by Sheldon and Bauer $(1959,1960)$, who found that acute alloxan diabetes in rats or rabbits seemed to lessen the intensity of the inflammatory exudate during experimental infection; they considered this a possible cause, in part, for the increased susceptibility to bacterial invasion. Not only were their animals glycosuric, but they were also quite ill from the effects of dehydration and ketosis. Perillie, Nolan, and Finch (1959) used the skin-window technique to show that cellular exudation was materially reduced in human diabetics with ketoacidosis, but not by hyperglycemia alone. So far, not a single report has established unequivocally that the hyperglycemia of diabetes mellitus alters the vigor of cellular exudation. If exudation after injury is in fact reduced in diabetics, and since inflammatory phagocytic cells are essential for an effective host defense, it becomes imperative to determine the influence of hyperglycemia upon the inflammatory response. Studies are currently in progress along these lines.

\section{ACKNOWLEDGMentS}

This investigation was supported by Public Health Service grants AI-02406-06 and TL-AI-69 from the National Institute of Allergy and Infectious Diseases.

\section{Literature Cited}

Allison, F., Jr., ANd M. H. Adcock. 1964. The influence of hydrocortisone and certain electrolyte solutions upon the phagocytic and bactericidal capacity of leukocytes obtained from the peritoneum of rats. J. Immunol. 92:435-445.

Bybee, J. D., ANd D. E. Rogers. 1964. The phagocytic activity of polymorphonuclear leukocytes obtained from patients with diabetes mellitus. J. Lab. Clin. Med. 64:1-13.

Croxton, F. E. 1953. Elementary statistics with application in medicine, p. 235. Prentice Hall Inc., New York.

Cruickshank, A. H., and T. P. B. Payne. 1949. Anti-pneumococcal powers of the blood in alloxan diabetes in the rabbit. Bull. Johns Hopkins Hosp. 84 :334-343.

Drachman, R. H. 1965. Phagocytic defence against bacterial infection in experimental diabetes mellitus. J. Clin. Invest. 44:1041.

Marble, A., H. J. White, and A. T. Fernald. 1938. The nature of the lowered resistance to infection in diabetes mellitus. J. Clin. Invest. $17: 423-430$.

Miles, A. A., E. M. Miles, ANd J. Burke. 1957. The value and duration of defense reactions of the skin to the primary lodgement of bacteria. Brit. J. Exptl. Pathol. 38:79-96.

Sheldon, W. H., and H. Baugr. 1959. The development of the acute inflammatory response 
to experimental cutaneous mucormycosis in normal and diabetic rats. J. Exptl. Med. 110: 845-852.

Sheldon, W. H., and H. Bauer. 1960. Tissue mast cells and acute inflammation in experimental cutaneous mucormycosis of normal, 48/80 treated, and diabetic rats. J. Exptl. Med. $112: 1069-1084$.

Smith, J. M., ANd R. J. Dubos. 1956. The effect of nutritional disturbances on the susceptibility of mice to staphylococcal infections. J. Exptl. Med. 103:109-118.
Sturtevant, F. M. 1956. Effect of insulin on glycosuria, polyuria, and food intake in alloxanized rats. Diabetes 5:388-390.

Perillie, P. E., J. P. Nolan, and S. C. Finch. 1959. Studies of the resistance to infection in diabetes mellitus: local exudative cellular response. J. Lab. Clin. Med. 59:1008-1015.

Wertman, K. F., and M. D. Henney. 1962. The effects of alloxan diabetes on phagocytosis and susceptibility to infection. J. Immunol. 89: 314-317. 